\title{
Management of Pregnancy on Sickle Cell Disease: A Case Report
}

\author{
Mohamed Adnane Rhaidouni ${ }^{1 *}$, Sofia Jayi ${ }^{1}$, Mohamed Adnane Berdai ${ }^{2}$, Ghizlane Berrady ${ }^{3}$, Fatima Zohra Fdili Alaoui ${ }^{1}$, \\ Alpha Boubacar Conte ${ }^{1}$, Hikmat Chaara ${ }^{1}$, Moulay Abdelilah Melhouf ${ }^{1}$ \\ ${ }^{1}$ Department of Gynecology - Obstetrics II, ${ }^{2}$ Intensive Care Medicine, ${ }^{3}$ Internal Medicine Sidi Mohamed Ben Abdellah University, \\ Department of Gynecology - Obstetrics II, Hassan II Teaching Hospital, Fez
}

DOI: $10.36348 /$ sijog.2021.v04i03.002

| Received: 21.02 .2021 | Accepted: 04.03.2021 | Published: 13.03.2021

*Corresponding author: Mohamed Adnane Rhaidouni

\section{Abstract}

SS homozygotic sickle cell disease combines chronic hemolytic anemia with vaso-occlusive and infectious complications. The association between Sickle cell disease and pregnancy is a maternal and fetal high-risk situation. Case description: A 27-year-old woman carrying a pregnancy on a sickle cell field with a history of miscarriage and hospitalization in critical care department for post-abortion septic shock. Her pregnancy was followed in our department in collaboration with internists, under aspegic, acfol and tardyferon and during the pregnancy, she received three blood transfusions and a caesarean section was planned at 39 weeks of gestation. She gave birth to a newborn weighing $3600 \mathrm{~g}$ in good condition. The post-partum was marked by a fortuitous discovery of IVC thrombosis. Conclusion: Sickle cell disease and pregnancy is a high-risk situation as we illustrate in our case. In addition to the absence of complications during pregnancy, post-partum also remains a period of risk even without obvious clinical manifestation

Keywords: Pregnancy; Sickle cell disease; Management.

Copyright (C) 2021 The Author(s): This is an open-access article distributed under the terms of the Creative Commons Attribution 4.0 International License (CC BY-NC 4.0) which permits unrestricted use, distribution, and reproduction in any medium for non-commercial use provided the original author and source are credited.

\section{INTRODUCTION}

Sickle cell disease is the most common genetic disease. Its transmission is recessive autosomal [1]. It corresponds to the synthesis of abnormal hemoglobin: hemoglobin S, different from normal hemoglobin: hemoglobin $\mathrm{A}$, following a mutation of the sixth codon of the hemoglobin chain beta-globin [2]. According to the WHO, nearly $5 \%$ of the world's population is carriers of a gene responsible for a hemoglobin abnormality; sickle cell disease affects approximately 25 million individuals with 312,000 newborns affected each year [3]. Sickle cell disease is a widespread entity that occurs in 7 to $8 \%$ of African Americans. It is particularly prevalent in sub-Saharan Africa (where rates can reach $40 \%$ in some regions), central India and the Arabian Peninsula [4]. Clinically, sickle cell disease in its homozygote form combines chronic hemolytic anemia, vaso-occlusive complications and susceptibility to infection [5].

The combination of sickle cell disease and pregnancy is a maternal and fetal high-risk situation. In the case of sickle cell and pregnancy, the risks and development of sickle cell attacks are increased and multidisciplinary care is essential (internists, resuscitators and obstetricians) [6]. We report in this manuscript a case of pregnancy that occurred on a sickle cell site. Through this case, we submit a brief review of the literature with a particular focus on the impact of pregnancy on sickle cell disease, the impact of sickle cell disease on pregnancy as well as the conduct to be held in the face of this situation.

\section{CASE PRESENTATION}

Mrs. Z.F. aged 27 years married with a notion of 1 st degree inbreeding who was followed in our department for the monitoring of sickle cell disease on a pregnancy of 36 weeks of gestation plus 4 days. She has no particular family history, and has been followed for sickle cell disease since 2016 diagnosed following a late abortion under ACFOL, Tardyferon and Aspégic. She is also being followed for a hip pathology. G3PO: her first pregnancy resulted in a miscarriage that occurred at the 4th month; her second pregnancy resulting in a late miscarriage at 22 weeks was characterized by the occurrence of lower limb edema arriving at the knees with dyskinesia of the lower limbs, 
Mohamed Adnane Rhaidouni et al; Sch Int J Obstet Gynec, Mar. 2021; 4(3): 55-57

exophthalmia, pruriginous skin spot and high blood pressure.

The progression in the post-partum was marked by the hospitalization in critical care department for the management of septic shock with post-abortum multi-visceral failure for which she benefited from a laparotomy showing an ischemia of the spleen that was respected. This led to an etiological research finding SS sickle cell disease. The third pregnancy is the one that was followed monthly in our department in consultation with the department of internal medicine. The course was without any particularity with acfol (folic acid), aspegic and tardyferon. Echocardiography during pregnancy was normal. No preeclampsia during pregnancy. She benefited of three blood transfusions and decision to hospitalize her at 37 weeks of amenorrhea.

At her admission, the examination found a stable, apyretic patient with a TA at $12 / 07 \mathrm{cmhg}$ and a negative urinary band. On the obstetrical level, uterine height was $29 \mathrm{~cm}$ without uterine contractions with positive and regular fetal heart pulse and a vaginal touch that found a normal pelvis. Note that the patient had difficulty to spread her legs. She received an obstetric ultrasound that found an evolutionary monofoetal pregnancy in cephalic presentation with a normal placenta and amniotic fluid, satisfactory biometrics and normal Dopplers (uterine and umbilical).

His biological balance revealed: $\mathrm{Hb}: 9,4 \mathrm{~g} / \mathrm{dl}$; Platelets: 508000; TP: 100\%; Urea: 0, 11; Creatine: 6; She was put on oral rehydration $(41 / 24 \mathrm{~h})$, preventive antihemostatic (Lovenox sc: $0.4 \mathrm{cc} / 24 \mathrm{~h}$ ) and transfused during her pregnancy with 4 red blood cells. A caesarean section was scheduled at 39 weeks with extraction of a male newborn, Apgar 10/10 with a birth weight of $3600 \mathrm{~g}$. The period of post-partum was marked on the 2 nd day by the accidental discovery during ultrasound examination a thrombosis of the proximal pulmonary artery, completed by a thoracic tom densitometry with discovery of a thrombus in the inferior vena cava, hence we use curative dose of antigoagulants, and she received rivaroxaban with no adverse effects. Currently the patient is followed by the internists.

\section{DISCUSSION}

Advances in the medical field have resulted in sickle cell disease reaching adulthood and these young homozygotic women can procreate, a rare event a few decades ago [2,7]. As a result, we are witnessing an increase in the frequency of pregnancy in debilitated field since childhood defining a very high-risk association, putting the life-threatening prognosis of these women at risk. In developing countries, which cannot benefit from this early management, the maternal and fetal mortality rate is still very high [8].
Pregnancy increases the risk of sickle cell complications, and conversely, sickle cell disease increases the risk of obstetric complications [9].

Acute complications of sickle cell disease that may occur with greater frequency include worsening of fetal and maternal anemia, vasoocclusive seizures, acute chest syndrome and infections. The physiological changes in pregnancy promote their appearance. Hemodilution anemia aggravates pre-existing anemia. The high demand for oxygen promotes the occurrence of an acute chest syndrome. Increased cardiac output can lead to poor ventricular compliance with difficulty filling during distal, which increases the risk of acute lung edema. Speaking of infections, these are most often-urogenital infections (vaginal infections, pyelonephritis) that cause premature births. However, these can be sometimes severe lung diseases, which cause respiratory problems and hypoxia [10-12].

The most common obstetric complications are pre-eclampsia and gravidating hypertension. There is also an increase in fetal morbidity with more intrauterine growth retardation, fetal death in utero and preterm births than in the general population, as well as miscarriages [13]. Placental hypoxia, due to chronic anemia, some abnormalities and placental microthrombosis reducing maternal-fetal exchange, are responsible for intrauterine growth retardation and fetal death. These placental abnormalities associated with microthrombosal-related kidney damage promote the occurrence of vasculo-renal syndromes and preeclampsia. Late miscarriages and prematurity are most often due to infections, which are common during pregnancy, but there is clearly a significant percentage of induced prematurity $[11,12]$.

The onset of these complications is explained by insufficient oxygen supply and the existence of placental ischemia associated with the presence of sickle cell disease in the placental circulation [14]. An increased proportion of caesarean section is associated with these maternal and fetal complications. Perinatal maternal mortality occurs mainly in postpartum in 1 to $2 \%$ of pregnancies despite improved management [13]. Obstetric follow-up combines regular consultations on a case-by-case basis. The most critical moment is from the third trimester to the postpartum to the delivery. Follow-up should incorporate the principle of the multidisciplinary approach and involve in a nonexhaustive way: the midwife, the obstetrician, the hematologist, the pediatrician, the infectious medical doctor, and the dietician.

Preventive means combine folic acid supplementation, monitoring of uterine velocometry as early as the 28th week, and iron intake under the reserve of the proven ferriprive nature of the anemia [15]. Blood transfusion remains an important problem in the management of these pregnancies. This 
Mohamed Adnane Rhaidouni et al; Sch Int J Obstet Gynec, Mar. 2021; 4(3): 55-57

transfusion has long been the subject of debate between proponents of prophylactic transfusion and those of point transfusion [8].

The French recommendations dating back to 2015, recommend the introduction of a transfusion program from 22-26 weeks of amenorrhea (SA) in case of relay of a background treatment with hydroxyurea, in cases of pre-existing severe organ damage (renal failure, heart failure), severe obstetric history, or the occurrence during pregnancy of a severe vasooclusive crisis, repeated seizures, acute chest syndrome or anemia with maternal and/or fetal clinical resonance. Outside of these clinical situations, blood transfusion remains punctual. The management of these pregnancies must therefore be multidisciplinary with a referring physician for sickle cell disease, a blood transfusion team and follow-up by gynecologicalobstetricians trained in sickle cell disease in a hospital with a neonatal critical care unit and a continuing care or adult critical care department [16]. Sickle cell disease does not itself represent an obstacle to the initiation of labour or the use of prostaglandins to mature the cervix [12]. The indication of the pathway of delivery is related to obstetric conditions and the condition of the mother as well as the impact of the disease on the pregnancy. After childbirth, the following moment represents a high-risk period. Patients should be reheated, rehydrated, oxygenated. Prevention of thrombosis and infection should be systematic in a resuscitation environment in the immediate postpartum setting [8].

\section{CONCLUSION}

The combination of sickle cell disease and pregnancy is a high-risk situation as we illustrate in our case. In addition to the absence of complications during pregnancy, the post-partum also remains a period of risk even outside of obvious clinical manifestation, as is the case with our patient. Hence the systematic search for complications.

\section{REFERENCES}

1. Mattioni, S., Stojanovic, K. S., Girot, R., \& Lionnet, F. (2016). La drépanocytose en France. Revue francophone des laboratoires, 2016(481), 61-66.

2. Arnal, C., \& Girot, R. (2002). Drépanocytose chez l'adulte. Encycl Méd Chir (Editions Scientifiques et Médicales Elsevier SAS, Paris). Hématologie, 13-006.

3. Oteng-Ntim, E. (2017). Pregnancy in women with sickle cell disease is associated with risk of maternal and perinatal mortality and severe morbidity. Evidence-based nursing, 20(2), 43-43.
4. Wilson, S., Ellsworth, P., \& Key, N. S. (2020). Pregnancy in sickle cell trait: what we do and don't know. British journal of haematology, 190(3), 328335.

5. Labie, D., \& Elion, J. (2010). La drépanocytose: problème de l'Afrique: SPECIAL DREPANOCYTOSE. Médecine tropicale, 70(5-6), 449-453.

6. Tebeu, P., Ngassa, P., Major, A., Ludicke, F., \& Doh, A. (2004). Grossesse sur drépanocytose avec complications maternelles et fœtales: Cas clinique et mise au point. Médecine d'Afrique Noire, 51(5), 293-297.

7. Ondo, S. A. (2008). Drépanocytose et grossesse: prise en charge de la gestante drépanocytaire (Doctoral dissertation).

8. Leborgne-Samuel, Y., Janky, E., Venditelli, F., Salin, J., \& Daijardin, J. B. (2000). Drépanocytose et grossesse: revue de 68 observations en Guadeloupe. Journal de gynécologie obstétrique et biologie de la reproduction, 29(1), 86-93.

9. Claire, M. (2018). Drépanocytose et grossesse. Gynécologie et obstétrique. dumas-01866727

10. Tsiba, F. G. A., Ocini, L. N., Itoua, C., BintseneMpika, G., Malanda, F., Doukaga, D. B., \& Dokekias, A. E. (2019). Drépanocytose et grossesse: expérience du centre national de référence de la drépanocytose de Brazzaville. Health sciences and disease, 20(2).

11. Leborgne-Samuel, Y., Kadhel, P.H., Ryan, C., Vendittelli, F. (2004). La Revue du praticien, 54:1578-1582.

12. Leborgne-Samuel, Y., Janky, E., Venditelli, F., Salin, J., \& Daijardin, J. B. (2000). Drépanocytose et grossesse: revue de 68 observations en Guadeloupe. Journal de gynécologie obstétrique et biologie de la reproduction, 29(1), 86-93.

13. Ribeil, J. A., \& Benachi, A. (2014). 11.2. Prise en charge de la grossesse chez les femmes atteintes d'un syndrome drépanocytaire majeur. Pathologies maternelles et grossesse, 301.

14. Barron, W., Lindheimer, M., Davison. (1990). Maladies hématologiques. J. Médecine de la femme enceinte. Paris: Flammarion MédecineSciences; 285-286.

15. Odum, C. U., Anorlu, R. I., Dim, S. I., \& Oyekan, T. O. (2002). Pregnancy outcome in HbSS-sickle cell disease in Lagos, Nigeria. West African journal of medicine, 21(1), 19-23.

16. Habibi, A., Arlet, J. B., Stankovic, K., GellenDautremer, J., Ribeil, J. A., Bartolucci, P., \& Lionnet, F. (2015). Recommandations françaises de prise en charge de la drépanocytose de l'adulte: actualisation 2015. La Revue de Médecine Interne, 36(5), 5S3-5S84. 